\title{
The Interaction Between Public and Private Enforcement of EU Competition Law: a Case Study of the Swedish Booking Cases
}

\author{
by
}

Katharina Voss*

\section{CONTENTS}

I. Introduction

II. The public enforcement against Booking

III. The private enforcement against Booking

1. The legal assessment of Booking's narrow MFN clauses

2. The burden and standard of proof

IV. Interactions between public and private enforcement

V. Conclusion

\begin{abstract}
This article studies the private enforcement conducted in Visita $v$ Booking from the perspective of the interaction between public and private enforcement of competition law. This case concerned the question whether the narrow MFN clauses maintained by Booking were contrary to Article 101 TFEU and could therefore be prohibited by a Swedish court. The focus of this article is placed on the assessment carried out by the Swedish courts to determine whether the MFN clauses were restrictive of competition by effect and on the standard of proof attached to the claimant in this regard. With regard to the interaction between public and private enforcement, Visita v. Booking is viewed as an illustration of the increased complexity of competition policy, in particular were novel practices are at issue.
\end{abstract}

* PhD in Law, Senior Lawyer at the Swedish Competition Authority; e-mail: katharina.voss@ kkv.se; ORCID: 0000-0002-5451-0992. The author would like to thank Martin Mandorff and the anonymous reviewers for their comments. The views stated in this article are the author's own and should not be construed as reflecting those of the Swedish Competition Authority.

Article received: 5 July 2019, accepted: 26 September 2019. 


\section{Résumé}

Cet article examine l'application privée pour les infractions aux dispositions du droit de la concurrence menée dans l'affaire Visita contre Booking en ce qui concerne l'interaction avec l'application publique du droit de la concurrence. Cette affaire portait sur la question de déterminer si les clauses de la Nation la Plus Favorisée restrictives appliquées par Booking étaient contraires à l'article 101 du TFUE et pouvaient donc être interdites par un tribunal suédois. Le présent article est centré sur l'évaluation effectuée par les juridictions suédoises afin de déterminer si les clauses de la Nation la Plus Favorisée étaient restrictives de la concurrence par effet et sur le niveau de preuve attaché à cet égard. En ce qui concerne l'interaction entre l'application publique et privée, l'affaire Visita v. Booking est considérée comme une illustration de la complexité accrue de la politique de concurrence, en particulier lorsque des pratiques nouvelles sont en cause.

Key words: Booking.com; EU competition law; MFN clause; OTAs; private enforcement; public enforcement.

JEL: K21, K42, L42

\section{Introduction}

The increased prominence of private enforcement of competition rules has been one of the most important developments in EU competition law in recent years. This development is mainly reflected in the adoption and implementation of Directive 2014/104/EU, which harmonised certain national rules governing private damages actions in cases where either Article 101 or 102 of the Treaty of the Functioning of the European Union (hereinafter: TFEU) or one of their national counterparts has been infringed. Moreover, the renewed focus on private enforcement may have led to increased attention on cases utilising previously existent possibilities for enforcement by private claimants. The present article examines the Swedish cases concerning the online travel agent (hereinafter: OTA) Booking and, in particular, the private enforcement cases between Visita (the sector organisation for hospitality in Sweden) and Booking. ${ }^{1}$ At the heart of these cases was the question whether so-called parity or most-favoured-nation clauses (hereinafter: MFN clauses) restrict competition in contravention of Article 101 TFEU.

\footnotetext{
1 Patent- och marknadsdomstolen, Judgment of 20 July 2018 (PMT 13013-16); Patent- och Marknadsöverdomstolen, Judgment of 9.05.2019 (PMT 779-18).
} 
This article, through its case study of Visita $v$ Booking, sheds light on two important issues where private enforcement may interact with public enforcement. The first issue relates to the fact that the correct legal assessment of MFN clauses remains contested. Where a private enforcement case pertains to a novel practice, divergent case law may be created by different courts. This problem points back to an issue related to public enforcement: As long as there is no precedent at EU level making a final legal assessment of MFN clauses, divergent judgments may be issued by national courts. ${ }^{2}$ Such judgments may even have repercussions on a competition authority's own commitment decisions, should they be in conflict with case law. The second issue is unrelated to the substance of the case, but nonetheless pertains to an issue well identified in commentary (Wahl, 2018), namely the tendency of courts to engage in more detailed assessments of the evidence used for claiming an infringement of competition law. ${ }^{3}$ So far, this development has mainly been discussed concerning the European Commission, but the Visita $v$ Booking cases show that questions related to the evidence required for proving that a certain practice has the object or effect of restricting competition have also found its way into private enforcement. Case law created in private enforcement cases may then in turn find its way into cases concerning public enforcement.

The remainder of this article is structured as follows: In section two, this article examines the public enforcement against Booking conducted by the Swedish Competition Authority (hereinafter: SCA). In section three, the private enforcement case between Visita and Booking is described and analysed. This analysis focusses on the legal assessments made by the national courts with regard to the potential restriction of competition of Booking's narrow MFN clauses as well as to the standard of proof required. Section four contains an analysis of the interaction between public and private enforcement on the example of these cases. Section five concludes.

2 Council Regulation (EC) No 1/2003 of 16 December 2002 on the implementation of the rules on competition laid down in Articles 81 and 82 of the Treaty ('Regulation 1/2003') [2003] OJ L1/1, art. 3(2); CJEU judgement of 23.11.2017, Case C-547/16 Gasorba, ECLI:EU:C:2017:891.

${ }^{3}$ See CJEU judgement of 8 December 2011, Case C-389/10 P, KME Germany AG, KME France SAS and KME Italy SpA v. European Commission, ECLI:EU:C:2011:816, paras. 121, 129. 


\section{The public enforcement against Booking}

The SCA initiated investigations against Booking and Expedia in 2013 and accepted commitments from Booking in 2015. ${ }^{4}$ The investigation against Expedia was dropped as Expedia changed its standard contract conditions to reflect Booking's commitments. ${ }^{5}$ The commitments offered by Booking were in parallel accepted by the French and Italian competition authorities. ${ }^{6}$

As already noted above, the SCA's investigations concerned so-called MFN clauses. The term 'MFN clause' originates from public international law designating a type of provision often used in international trade agreements, ${ }^{7}$ '[...] whereby a state undertakes an obligation towards another state to accord most-favoured-nation treatment [...]'. ${ }^{8}$ In the present context, MFN clauses usually oblige one party to an agreement to offer the same or similar favourable conditions to the other party, as those granted to third parties.

MFN clauses are used by Booking in its standard contracts with hotels, whereas Booking offers an OTA for hotel rooms (at a commission). At the same time, hotels usually offer room-booking services directly to customers as well. Beyond room-booking services, Booking also provides customers with a comparison function and hotels with larger visibility among customers. If hotels were allowed to undercut the prices on comparison sites, they could free ride on the benefits provided by Booking. In practical terms, this problem was eliminated by MFN clauses.

While MFN clauses aim to prevent free riding, they may also have anticompetitive effects if they are applied in a broad manner. In this context, it has become common to distinguish between narrow and wide MFN clauses (Ezrachi, 2016, p. 194-197). With regard to Booking's business, its narrow MFN clauses only require parity between Booking and the hotels in the sales channel employed by Booking, that is online. Its wide MFN clauses, by contrast, also required price parity compared with other OTAs and included several sales channels (for example, both online and offline sales). MFN

4 Swedish Competition Authority, Decision of 15 April 2015, Bookingdotcom (dnr. 596/2013).

5 Swedish Competition Authority, Decision of 10 June 2014, Expedia (dnr. 595/2013).

6 French Competition Authority, Decision of 21 April 2015, Booking, http://www. autoritedelaconcurrence.fr/pdf/avis/15d06.pdf, last visited 10 June 2019; Italian Competition Authority, Decision of 21 April 2015, Booking, https://www.agcm.it/dotcmsDOC/allegati-news/ I779_chiusura.pdf, last visited 10.06.2019.

${ }^{-}$See e.g.: Article 1 of General Agreement on Tariffs and Trade (adopted 30 October 1947, entered into force 1 January 1948) 55 UNTS 187 (GATT 1947).

8 United Nations International Law Commission, 'Draft Articles on Most-Favoured-Nation Clauses' available in 'Report of the International Law Commission on the Work of its $30^{\text {th }}$ Session' (8 May-28 July 1978) UN Doc A/33/10, Article 4. 
clauses can also be used for contractual conditions not related to price and to potentially innovative products or services, as the Amazon e-Books case shows. ${ }^{9}$ Wide MFN clauses may eliminate price competition between retailers and are a way of controlling markets, especially for strong market actors that are more likely to negotiate MFN clauses for themselves. By way of wide MFN clauses, strong actors are guaranteed that they can always offer the lowest price on a given product, thus making it impossible for smaller undertakings to attract customers by undercutting prices (Ezrachi, 2016, p. 194-197).

The commitments offered by Booking and subsequently made binding by the SCA meant that Booking abandoned its wide MFN clauses, but retained the narrow MFN clauses, meaning that hotels could not price differentiate between their online presence and the prices offered on Booking's site. However, hotels could differentiate their prices between different OTAs and could differentiate prices in other sales channels, for example concerning room bookings via phone or in member's clubs. ${ }^{10}$

In contrast to the commitments accepted by the Italian, French and Swedish competition authorities, the German competition authority prohibited both narrow and wide MFN clauses as implemented by Booking in Germany (see further: Leslie, 2018). ${ }^{11}$ That decision was subsequently appealed to the Higher Regional Court (hereinafter: OLG) in Düsseldorf. In the appeal of the German authority's decision against Booking's narrow MFN clauses, OLG Düsseldorf found that Booking's narrow MFN clauses (in Germany) infringed Article 101 TFEU, but considered the clauses to be ancillary restraints exempted from the application of Article 101 TFEU. ${ }^{12}$ Thus, in conclusion, the outcome based on the application of competition rules has been the same in all four jurisdictions: While Booking's wide MFN clauses have been removed, its narrow MFN clauses have been allowed to remain in practice. Also, the different outcomes arrived at by different national competition authorities did not formally clash with each other as they pertained to different jurisdictions. However, as will become apparent from the case study below, certain dissonances in the legal assessments appear when analysing the judgements by the Swedish courts vis-à-vis that of OLG Düsseldorf briefly described above.

9 e-Book MFNs and related matters (Case AT.40153) Commission Decision C(2017) 2876 [2017] OJ C 264/7.

10 Swedish Competition Authority, Decision of 15 April 2015, Bookingdotcom (dnr. 596/2013), p. $12-19$.

11 German Competition Authority, Decision of 22 December 2015, Meistbegünstigungsklauseln bei Booking.com (B 9-121/13).

12 OLG Düsseldorf, Judgment of 4 June 2019 (VI-Kart 2/16 (V)). 


\section{The private enforcement against Booking}

In the Swedish Competition Act, ${ }^{13}$ provision is made for undertakings to gain standing in cases where the SCA has decided not to prohibit a practice previously investigated as a potential infringement of Article 101 or 102 TFEU as well as their national counterparts where that undertaking can show that it is affected by the SCA's decision. In such cases, undertakings may apply to the Patent- and Markets Court (hereinafter: PMD) for a prohibition of the practices which are in contravention of Article 101 TFEU, 102 TFEU and/or one of their national counterparts.

This provision, found in chapter 3, § 2 of the Swedish Competition Act, was employed by Visita to apply for a prohibition of the narrow MFN clauses maintained by Booking. In the first instance court, PMD, Booking's narrow MFN clauses were considered to be in contravention of Article 101 TFEU, while the second instance Court, the Patent and Market Appeal Court (hereinafter: PMÖD) came to the opposite conclusion. Below, the reasoning of each Court is detailed further. That examination focusses on two aspects in the respective judgments: First, the assessment of narrow MFN clauses with regard to whether they form a restriction of competition. Second, the placement and standard of the burden of proof applied by each Court.

\section{The legal assessment of Booking's narrow MFN clauses}

Considering the substance of the case, the focus of the Visita $v$ Booking judgement is undoubtedly on the question whether the narrow MFN clauses restrict competition by object or effect.

Reviewing the legal reasoning by the Swedish Courts, the lower instance court, PMD, defines two relevant markets: The market for booking-services for hotel-rooms (the market on which OTAs are active) and the market for hotel nights (the market on which hotels are active). Before considering whether Article 101(1) TFEU is infringed by Booking's narrow MFN clauses, PMD reviews whether these are an ancillary restraint of Article 101 TFEU. After answering that question in the negative, PMD assesses whether Booking's narrow MFN clauses infringe Article 101(1) TFEU. Subsequently, PMD considers whether the narrow MFN clauses can fall within the exemption in Article 101(3) TFEU. In sum, PMD finds that the clauses restrict competition by effect and therefore infringe Article 101(1) TFEU.

13 Konkurrenslagen (2008:579). 
In relation to the restriction of competition between OTAs, PMD finds that hotels will, as a rule, not offer a certain price on an OTA if they cannot offer the same price on their own website. Hotels that are bound by a narrow MFN clause therefore have no incentive to price-differentiate between OTAs. This circumstance, in turn, makes it difficult for new OTAs to compete based on price. PMD draws the conclusion that the narrow MFN clauses imposed by Booking have at least a potential restrictive effect on competition. ${ }^{14}$

With regard to the assessment of the restriction of competition between hotels, PMD considers that Booking's narrow MFNs restrict hotels from setting lower prices on their own websites compared to the prices offered on Booking's website. PMD recalls that hotels have lower costs for room bookings made on their own website (ca. 4-6\% of the room price) as compared to bookings made on Booking's website (ca. 15\% of the room price). Thus, PMD considers that hotels, in the absence of the narrow MFN clause, would take advantage of these lower costs and would thus set lower prices on their own websites. Just as in relation to the OTA market, PMD finds that Booking's narrow MFN clauses potentially restrict competition by effect on the market for hotel nights. ${ }^{15}$

As already noted, PMÖD comes to the opposite conclusion, namely that Booking's narrow MFN clauses have neither the object nor the effect of restricting competition. With regard to the restriction of competition between OTAs, it appears that the evidence submitted by Visita, showing that hotels do not price-differentiate because of Booking's narrow MFN clauses did not convince PMÖD. Instead, PMÖD considers that the fact that hotels do not price differentiate between different sales channels may be due to a number of different reasons, for example price-transparency on the market or constraints in IT-systems. ${ }^{16}$

With regard to the restriction of competition between hotels, the assessment made by PMÖD is similar. The Court is not convinced that hotels, in the absence of narrow MFN clauses, would set lower prices on their own websites. In particular, it appears that PMÖD would have required a study of the market situation in countries where the use of narrow MFN-clauses was (at the time) forbidden, particularly Germany and France. ${ }^{17}$

In the light of PMÖD's judgment, rejecting Visita's claim that Booking's narrow MFN clauses infringe Article 101(1) TFEU based on insufficient evidence, it is particularly interesting to consider how the burden and standard

14 Patent- och marknadsdomstolen, judgment of 20 July 2018 (PMT 13013-16); Patent- och Marknadsöverdomstolen, judgment of 9 May 2019 (PMT 779-18), p. 48.

15 Ibidem, p. 49-50.

16 Patent- och Marknadsöverdomstolen, Judgment of 9 May 2019 (PMT 779-18), p. 18-20.

17 Ibidem, p. 22-23. 
of proof were treated by both PMD and PMÖD. As already noted in the introduction, private enforcement of competition rules may lead to case law developing important and even contested issues regarding the application of competition law. This case law may in turn have an impact on the application of competition rules in public enforcement, both by competition authorities and by national courts.

\section{The burden and standard of proof}

Questions concerning the standard of proof have been much discussed in the application of EU competition law (see for example: Ibáñez Colomo and Lamadrid, 2016; Geradin and Petit, 2010). This relates both to how broad the 'margin of appreciation' granted to the Commission should be in abstract, ${ }^{18}$ and with regard to more substantive questions, notably the question of how an analysis of whether a certain behaviour restricts competition should be carried out. ${ }^{19}$ Even though the judgments discussed in the present article concern cases of private enforcement, the abovementioned lines of case law have had an important impact on the reasoning of these courts.

With regard to the burden of proof, PMD begins by recalling the principle of national procedural autonomy. ${ }^{20}$ Subsequently, it acknowledges that Article 2 of Regulation 1/2003 defines who should bear the burden of proof showing that Article 101(1) TFEU has been infringed, namely the party making such a claim. ${ }^{21}$ This placement of the burden of proof is also in congruence with Swedish procedural law. ${ }^{22}$

As to the standard of proof required of a claimant, PMD notes that there is no competence at EU level for defining the standard of proof, but that the principles of equivalence and effectiveness must be observed, meaning that the exercise of rights deriving from EU law may not be made excessively difficult or impossible. ${ }^{23}$ PMD then states that the standard of proof should be set at the same level as is common in Swedish civil cases of this kind, that is, at a 'demonstrated' level. This standard is under Swedish law considered to

18 Case C-389/10 P KME Germany AG, KME France SAS and KME Italy SpA v. European Commission, paras. 121, 129.

19 CJEU judgment of 11 September 2014, Case C-67/13 P Groupment des Cartes Banational v. European Commission, ECLI:EU:C:2014:2204, paras. 53-54. See, for a useful consolidation of the case law in this respect: Opinion of AG Bobeck in Case 228/18 Gazdasági Versenyhivatal v. Budapest Bank Nyrt. and others, ECLI:EU:C:2019:678.

20 Patent- och marknadsdomstolen, Judgment of 20.07.2018 (PMT 13013-16), p. 29.

21 Regulation 1/2003, art. 2.

22 Patent- och marknadsdomstolen, judgment of 20.07.2018 (PMT 13013-16), p. 29.

23 Ibidem, p. 30. 
be set below the standard for criminal case, that is 'beyond reasonable doubt', but above the lower civil standard of 'probable' (Heuman, 2005, p. 66-67) or, 'more likely than not'. One may argue that the standard of 'demonstrated' roughly equals that of 'clear and convincing evidence' used in the Anglo-Saxon tradition.

Even though Regulation 1/2003 explicitly states that it does not affect the standard of proof applied by national courts, it is interesting to note that PMD does not refer to the Court of Justice of the European Union (hereinafter: CJEU) concerning the standard of proof to be applied when considering the case at hand. ${ }^{24}$ The CJEU has in this respect held that the Commission, when alleging an infringement of Article 101 or 102 TFEU, should bring forward 'sufficiently precise and consistent evidence'. ${ }^{25}$ As Gippini-Fournier convincingly argues, the CJEU draws strongly from a continental tradition of 'free evaluation of evidence' rather than a common law tradition of succinctly defining different standards of proof (Gippini-Fournier, 2010, p. 5-7).

It must be noted in this context that the Swedish legal tradition can be categorised as somewhat of a 'hybrid' between the common law and civil law traditions. With regard to the standard of proof required by Swedish courts, there is on the one hand a tradition of defining specific standards of proof. On the other hand, Swedish courts also apply the principle of 'free evaluation of proof'. This means that, while defining a certain standard of proof, Swedish courts remain relatively free to take into account and evaluate all the evidence presented to them. ${ }^{26}$

In Visita $v$ Booking, PMD simply notes that, under national rules, the same standard of proof ('demonstrated') applies to infringements of Article 101 TFEU as to the relevant national provision, chapter $2, \S 1$ of the Swedish Competition Act. ${ }^{27}$ Thus, PMD considers that the principles of equivalence and effectiveness are not violated by applying 'demonstrated' as the relevant standard of proof.

In contrast to the abstract reasoning on the standard of proof to be required, PMD relies largely on the case law from the CJEU when considering how the examination of whether or not Booking's narrow MFN clauses infringe Article 101 TFEU should be carried out, also with regard to the proof required. For example, as to whether the relevant MFN clauses have the effect of restricting competition, PMD considers that it follows from

${ }^{24}$ Regulation $1 / 2003$, recital 5 . This is in contrast to another recent judgment by the same Court, namely Patent- och marknadsdomstolen, judgement of 21.01.2019 (PMÄ 2741-18), p. 15.

${ }^{25}$ CJEU judgment of 25 January 2007, joined Cases C-403/04 P and C-405/04 P Sumitomo Metal Industries v. Commission, ECLI:EU:C:2007:52, para. 42.

26 Rättegångsbalken (1942:740), 35 kap. 1 § (Code of Procedure, chapter 35, § 1).

27 Patent- och marknadsdomstolen, judgment of 20 July 2018 (PMT 13013-16), p. 30. 
Maxima Latvija ${ }^{28}$ and Ordem dos Técnicos Oficiais de Contas $^{29}$ that such an examination must not only consider the factual effects of these clauses but also potential ones. ${ }^{30}$ After examining the evidence brought forward by the parties, PMD states that Booking's narrow MFN clauses can be considered to have 'at least a potential effect restricting competition'. ${ }^{31}$ When studying how PMD examines the evidence brought forward by the parties, it seems almost as if it puts aside its previous finding that Visita should demonstrate that the narrow MFN clauses should have the effect of restricting competition. While PMD appears to brush aside the weaknesses in the evidence presented by Visita, ${ }^{32}$ weaknesses found in the evidence presented by Booking appear to be taken very seriously by PMD. ${ }^{33}$ The impression is that the Court, in assessing the effect of narrow MFN clauses relies mainly on an overall assessment of all the evidence brought forward in the case, instead of concentrating on what Visita is able to 'demonstrate'. Such an assessment would indeed be in line with what Gippini-Fournier argues to be the 'standard' of proof before the CJEU, namely 'intimate conviction' (Gippini-Fournier, 2010, p. 6).

A contrasting approach can be identified in the judgment of the appeal court, PMÖD. That court does not define a succinct standard of proof, but is very specific in that is demands Visita to show that the narrow MFN clauses infringe Article 101(1) TFEU and its counterpart in national legislation. ${ }^{34}$ When considering the effect of restricting competition, PMÖD holds that: 'To substantiate its action, it is up to Visita to show that the claims made in the case follow from factual circumstances. That there are possibilities to show actual effects on the market may for example follow from the fact that that the agreement or concerted practice at issue has been in effect for a long time when assessing it. It is reasonable to assume that a possible restrictive effect on competition has already arisen, which strongly suggests, according to the principle of the best available evidence, that the claimant must show such an actual effect for the Court to be able to conclude that the standard of proof is fulfilled. However, it is not excluded that the claimant can provide other sufficiently robust evidence of the actual or potential effects of the clause that could satisfy the standard of proof. ${ }^{35}$

28 CJEU judgment of 26.11.2015, Case C-345/14 Maxima Latvija, ECLI:EU:C:2015:784, para. 30 .

29 CJEU judgment of 28.02.2013, Case C-1/12 Ordem dos Técnicos Oficiais de Contas, ECLI:EU:C:2013:127, para. 71.

${ }^{30}$ Patent- och marknadsdomstolen, judgment of 20 July 2018 (PMT 13013-16), p. 41.

31 Ibidem, p. 48. Translation by the author.

32 Ibidem, p. 46.

33 Ibidem, p. 47.

34 Patent- och Marknadsöverdomstolen, Judgment of 9 May 2019 (PMT 779-18), p. 17-18.

35 Ibidem, p. 18. Translation by the author. 
Thus, PMÖD considers that it is up to Visita to prove actual anti-competitive effects flowing from Booking's narrow MFN clauses. In this regard, PMÖD appears to go beyond what has been held by the CJEU. ${ }^{36}$ PMÖD thus examines whether Visita had been able to prove actual anti-competitive effects. At the end of that examination, PMÖD concludes that the evidence submitted by Visita is not 'robust enough' to substantiate that claim. ${ }^{37}$

The impact of the two national court's judgments with regard to their assessment of evidence on future cases remains to be seen. It appears likely that the high requirements of the evidence brought forward by the claimant with regard to the effect of restricting competition will have a continuing impact on future case law. The declared standard of proof by the lower instance court, though not contradicted by the appeal court, appears less likely to have a continued impact. A simple standard of proof, without clear reasoning to fill this 'shell' is unlikely to be particularly useful in future cases. The standard of proof applied by PMÖD may not only have an impact on private claimants, but also on the SCA, whose cases are heard in the same two courts. Furthermore, the judgment by PMÖD follows the observed tendency of the CJEU to review evidence presented by the Commission in cases alleging an infringement of competition law more thoroughly (Wahl, 2018). Admittedly, this tendency may be because competition law enforcement increasingly concerns practices that are not easily categorised as having as their object the restriction of competition. However, this same tendency also makes it difficult for both undertakings and competition authorities to determine which practices are permissible according to competition rules and which are not.

\section{Interactions between public and private enforcement}

An observation already made above is that the legal assessment of narrow MFN clauses has differed across courts and jurisdictions. In particular, it can be recalled that OLG Düsseldorf considered Booking's narrow MFN clauses to infringe Article 101 TFEU, but exempted them as ancillary restraints. Meanwhile, PMD did not consider the MFN clauses to be ancillary restraints. PMÖD did not find that Visita had proven that Booking's narrow MFN had the effect of restricting competition. Further, as both PMD and PMÖD observed when considering whether Booking's narrow MFN clauses restrict

\footnotetext{
36 See e.g. the judgments in C-345/14 Maxima Latvija and C-1/12 Ordem dos Técnicos Oficiais de Contas, cited above.

37 Patent- och Marknadsöverdomstolen, judgment of 9 May 2019 (PMT 779-18), p. 24.
} 
competition by object, there is also no agreement on the legal or economic assessment of narrow MFN clauses among academics or legislators. ${ }^{38}$

It could be argued, as done by Andreas Mundt, President of the German competition authority, that the differences pointed out above can be explained by different market conditions in different jurisdictions (Kalthoff, Pracht and Jegminat, 2018, p. 22). Yet, based on the differing views present in academic literature (see for example: Colangelo, 2017, p. 10-15), it could also be argued that these differences have their root in a lack of consensus how to appropriately assess narrow MFN clauses, both from a legal and from an economic point of view. This conclusion would, as such, be neither surprising nor problematic, given that the use of MFN clauses overall is a relatively new phenomenon within the context of internet platforms. However, what must be considered here is the role of precedent at the EU level.

The Commission has previously adopted two decisions specifically dealing with the issue of MFN clauses: Apple e-Books and Amazon e-Books, both closed by commitment decisions. While these decisions did not concern hotelbooking platforms, the MFN clauses at issue were relatively similar to those at issue in the Booking case. For instance, in the Apple e-Books case, agreements between Apple and a number of e-Book publishers were at issue. ${ }^{39}$ Essentially, the agreements included MFN clauses that obliged e-Book publishers to offer Apple the same retail prices they offered to any other e-Book retailer if this price was lower than the current retail prices offered to Apple. ${ }^{40}$ The e-books cases differ from the Booking cases in the sense that they concern mostly wide MFN clauses. Still, a decision containing a final legal assessment of the MFN clauses at issue in at least one of these cases could have helped clarify the framework of assessment that should be applied to MFN clauses. From the point of view of private claimants, the commitment decisions adopted in these cases were thus a regrettable outcome.

Unfortunately also, the Commission has not addressed in a satisfactory manner the question of the assessment of MFN clauses in general guidance. The Commission has included MFN clauses in its sector inquiry concerning e-commerce. The final report finds that actors in the e-commerce market are using MFN clauses, though they are not overly common. As regards the lawfulness of MFN clauses, the Commission considers that they fall within the broad scope of the Vertical Block Exemption Regulation, as long as the actors in question fulfil the market share limits and the parity clauses do not present

38 Patent- och marknadsdomstolen, judgment of 20 July 2018 (PMT 13013-16), p. 39; Patentoch Marknadsöverdomstolen, Judgment of 9.05.2019 (PMT 779-18), p. 15.

39 e-Books (Case COMP/39.847) Commission Decision C(2013) 4750 [2013] OJ C 378/25.

${ }^{40}$ Ibidem, paras. 35-36. 
a hard-core restriction of competition..$^{41}$ Otherwise, the clauses would need to be examined individually. The Commission's line of reasoning regarding the potential restriction of competition and benefits for competition is rather short, only three paragraphs. It does not provide any conclusions as to the probable lawfulness of, for example, narrow versus broad MFN clauses. ${ }^{42}$

Summing up, there is no concrete guidance on the legal assessment of MFN clauses at EU level as of yet. However, it appears that the need for guidance on the legal assessment of MFN clauses is being discussed in connection with the current review of the Vertical Block Exception Regulation (Hirst, 2019). In any case, it appears desirable that a legal precedent as to the assessment of MFN clauses be established at the EU level (see further: Caccinelli and Toledano, 2018, p. 232; Colangelo, 2017, p. 10-15). ${ }^{43}$ A decision by the Commission, reviewed by the CJEU or, alternatively, a preliminary reference from a national court, would provide much needed legal certainty. While different outcomes with regard to different MFN clauses could still be the result, a framework for the assessment of different MFN clauses is much needed.

Concerning the dynamics between public and private enforcement, it can also be recalled that the SCA had accepted commitments that required the removal of Booking's wide MFN clauses in $2015 .{ }^{44}$ Even though the SCA's decision makes no declaration with regard to the narrow MFN clauses, these were implicitly accepted since the SCA considered that Booking's commitments removed the SCA's competition concerns. ${ }^{45}$ In this context, it can be considered what impact the Visita $v$ Booking case may have on the SCA's commitment decision if PMÖD had also considered Booking's narrow MFN clauses to be anti-competitive?

Considering the function of chapter $3, \S 2$ of the Swedish Competition Act (the provision employed by Visita to claim that Booking should remove its narrow MFN clauses), this provision gives private claimants the right to seek a Court order removing an infringement of competition rules that has not been prohibited by the national competition authority. This provision hence

41 See Commission Regulation 330/2010 of 20 April 2010 on the application of Article 101(3) of the Treaty on the Functioning of the European Union to categories of vertical agreements and concerted practices [2010] OJ L 102/1.

${ }^{42}$ European Commission, 'Report from the Commission to the Council and the European Parliament: Final Report on the E-Commerce Sector Inquiry' SWD(2017) 154 final, paras. 621-23.

43 Such a decision could be based on either Article 7 (prohibition decision) or Article 10 (non-application decision) of Regulation 1/2003.

44 See section 2.

45 Swedish Competition Authority, Decision of 15 April 2015, Bookingdotcom (dnr. 596/2013), para. 50 . 
complements the power of the SCA to issue such an order. Legally speaking, this procedure is not a review procedure where the decision of the SCA is examined. Thus, there could not have been any direct contradiction between the SCA's commitment decision and the judgement of PMÖD in the case of Booking. Had PMÖD found Booking's narrow MFN clauses to be anticompetitive, Booking would have had to abolish these clauses. This would have been a more far-reaching result than that reached by the commitment decision concluded with the SCA, but not in direct contradiction with it.

Nevertheless, it is possible to imagine a conflict arising between commitments accepted by the SCA and a Court order issued in a private enforcement case where the duties arising for the undertaking(s) infringing competition rules are more complex. For example, suppose that the SCA accepts commitments relating to access to a natural monopoly controlled by a dominant undertaking. If a court subsequently orders a different remedy, such as the divestiture of certain parts of that natural monopoly, the commitments and the court order may stand in direct conflict with one another. ${ }^{46}$ Such conflicts would arguably arise more easily if the legal assessment of a certain behaviour by the SCA (albeit implicitly) and the Court diverge. This situation, in turn, is more likely in cases concerning novel issues that have not previously been assessed by the Commission or the Court in a binding manner.

The Visita $v$ Booking case thus illustrates that uncertainty as to the legal assessment of novel issues in competition law can have far-reaching consequences, where diverging judgments stemming from private enforcement of competition rules could have implications on public enforcement, at least within the concerned EU Member State. With regard to the concrete situation in this case, a commitment decision under Swedish Law does not contain a final assessment of the legality of the behaviour at issue. ${ }^{47}$ Thus, potential conflicts would only relate to the practical consequences of the SCA decision vis- $a$-vis the Court judgment and not to the legal assessment. Nevertheless, the point that should be stressed here is that the treatment of novel issues by way of commitment decisions may not only contribute to legal uncertainty in public enforcement, but also, by extension, in private enforcement of competition law.

46 With regard to remedies available under Swedish competition law, see the relevant preparatory works: Prop. 1992/39:56, p. 90.

47 Konkurrenslagen (2008:579), 3 kap. 4 § (Swedish Competition Act, chapter 3, § 4). 


\section{Conclusion}

This article has analysed the private enforcement case between Visita and Booking from the perspective of the interaction between public and private enforcement. The focus of the case study carried out in this article has been the legal assessment of Booking's MFN clauses and the standard of proof applied. Rather unsurprisingly, it can be observed that the Swedish courts involved develop case law relevant for public enforcement also in private enforcement cases. This may be particularly relevant in the Swedish context were the same courts (PMD and PMÖD) are competent to hear both: cases brought by the SCA, and cases brought by private claimants based on chapter $3, \S 2$ of the Swedish Competition Act.

An overall conclusion that may be drawn from this case study is that private enforcement adds further complexities to public competition policy, especially in the interaction between considerations of procedure and considerations of legal certainty. This interaction is particularly relevant with regard to the Commission, who is the primary enforcer of competition rules in the EU. The Commission is, on the one hand, faced with increasingly intensified legal review by the CJEU. To use its scarce resources effectively, it is reasonable to conclude certain cases by cooperative procedures such as commitments and settlements. The Commission must, on the other hand, consider that the substantial enforcement of competition rules conducted at Member State level demands that precedent is created at the EU level which can than guide enforcement at the national level. Given that most national courts are not required, by virtue of Article 267 TFEU, to refer questions to the CJEU, it appears risky to rely on national courts for the creation of such precedent.

\section{Literature}

Caccinelli, C., \& Toledano, J. (2018). Assessing Anticompetitive Practices in Two-Sided Markets: the Booking.Com Cases. Journal of Competition Law \& Economics, 14(2), 193-234. http://dx.doi.org/10.1093/joclec/nhy005

Colangelo, M. (2017). Parity Clauses and Competition Law in Digital Marketplaces: The Case of Online Hotel Booking. Retrieved from https://papers.ssrn.com/sol3/papers. cfm?abstract id $=2963503$

Ezrachi, A. (2016). EU Competition Law: An Analytical Guide to the Leading Cases. Oxford and Portland, Oregon: Hart.

Geradin, D., \& Petit, N. (2010). Judicial Review in European Union Competition Law: A Quantitative and Qualitative Assessment. Retrieved from: https://papers.ssrn.com/ sol3/papers.cfm?abstract_id $=1698342$ 
Gippini-Fournier, E. (2010). The Elusive Standard of Proof in EU Competition Cases. Retrieved from: https://papers.ssrn.com/sol3/papers.cfm?abstract_id $=1433744 \&$ download $=$ yes (04.07.2019).

Heuman, L. (2005). Bevisbörda och beviskrav i tvistemål. Stockholm: Norstedts Juridik.

Hirst, N. (2019, June 13). EU's vertical agreements review to include RPM, MFN, selective distribution, official says. MLex. Retrieved from: http://www.mlex.com/GlobalAntitrust/ DetailView.aspx? cid=1100634\&siteid=190\&rdir=1 (04.07.2019).

Ibáñez Colomo, P., \& Lamadrid, A. (2016). On the Notion of Restriction of Competition: What We Know and What We Don't Know We Know. Retrieved from: https://papers. ssrn.com/sol3/papers.cfm?abstract_id $=2849831$

Kalthoff, M., Pracht, S., \& Jegminat, G. (2018). Wie Deutschlands Wettbewerbshüter Andreas Mundt die Digitalgiganten in den Griff bekommen will. FVW Magazin. Retrieved from: https://www.bundeskartellamt.de/SharedDocs/Publikation/ DE/Interviews/2018/180316_FVW_Magazin.pdf?_blob=publicationFile\&v=2 (04.07.2019).

Leslie, W. (2018). Online Booking Platforms, MFNs and the Vertical Block Exemption: The Need for Certainty. European Competition Law Review, 39(7).

Wahl, N. (2018). Recent Trends at the Court of Justice of the European Union. Concurrences: Revue Des Droits de La Concurrence, (4). 